\title{
Selvmord og psykiske lidelser
}

\author{
En av de mest etablerte «sannheter» om selvmord er at psykiske lidelser spiller en viktig rolle ved minst \\ $90 \%$ av dem. I dette ligger også en antakelse om årsakssammenheng. Evidensbasen for denne «sannheten» \\ er imidlertid tvilsom fordi den er fremkommet ved studier som ikke holder mål. Her diskuteres noen alvorlige \\ implikasjoner av dette.
}

\author{
Heidi Hjelmeland \\ heidi.hjelmeland@svt.ntnu.no \\ Gudrun Dieserud \\ Kari Dyregrov \\ Birthe Loa Knizek \\ Mette Lyberg Rasmussen
}

Det gjentas til stadighet, både i faglitteraturen og i media, at psykiske lidelser spiller en sentral rolle ved ni av ti selvmord $(1-3)$. Evidensbasen for denne «90\%-sannheten» består hovedsakelig av en lang rekke psykologiske autopsistudier (PA-studier) (3), der man basert på intervjuer med etterlatte har stilt psykiatriske diagnoser på avdøde, ofte mange år etter selvmordet. Slike studier er imidlertid beheftet med alvorlige metodiske problemer (4), særlig knyttet til den diagnostiske prosessen der man diagnostiserer noen (avdøde) basert på intervjuer med andre (etterlatte) (5). Det hevdes imidlertid at så lenge man bruker standardiserte diagnostiske instrumenter, er funn fra slike studier både reliable og valide $(4,6)$.

Går man de spørsmål som inngår i slike standardiserte diagnostiske instrumenter, nærmere etter i sømmene, blir det imidlertid klart at mange av dem ikke kan besvares reliabelt av andre enn den som skal diagnostiseres (se 5 for eksempler). $\mathrm{Og}-$ dersom spørsmålene ikke kan besvares reliabelt, kan ikke diagnosene som stilles, bli valide (5).

Det kan virke som om den sterke sammenhengen mellom psykiske lidelser og selvmord har fått status som faktum kun basert på et stort antall studier av samme type. Det hjelper imidlertid ikke at et funn gjentas i aldri så mange studier, hvis studiene ikke er egnet til å besvare forskningsspørsmålet (5).

\section{Som man spør, får man svar?}

Intervjuer man etterlatte etter et selvmord ut fra et diagnostisk spørreskjema, slik man gjør i tradisjonelle PA-studier, er muligheten relativt stor for at man ender opp med en diagnose på avdøde. Dette går tydelig frem av Cavanagh og kollegers omfattende review-studie (3). Slike diagnoser er imidlertid basert på etterlattes subjektive oppfatninger, følelser og erfaringer, eller spekulasjoner om spørsmål de i mange tilfeller ikke har mulighet til å kunne svare sikkert på, på vegne av avdøde (5). Lar man derimot de etterlatte snakke fritt om det de tenker var sentralt for selvmordet, blir bildet et helt annet.

Et tydelig eksempel på dette er en PA-studie fra England (7, 8). I første del av denne studien svarte informantene på diagnostiske spørsmål. $68 \%$ av de avdøde ble da funnet å kvalifisere til en psykiatrisk diagnose (7). Da den narrative delen av intervjuene med de samme informantene ble analysert kvalitativt, viste det seg imidlertid at svært få snakket om psykiske lidelser som sentralt for selvmordet (8).

I Norge er det nå gjennomført to kvalitative PA-studier, der flere etterlatte rundt hvert selvmord har fătt fortelle sin historie om hva som førte til selvmordet. I sin studie av selvmord blant eldre (65-90 år) fant Kjølseth at selvmord hadde å gjøre med hvem avdøde hadde vært, hvordan de hadde levd sitt liv ut fra de gitte forutsetninger, og hva deres erfaringer betydde for møtet med alderdommen (9). Mange hadde levd under svært vanskelige forhold, både i oppveksten (med for eksempel tap av viktige omsorgspersoner, sykdom og fattigdom) og senere $i$ livet (alvorlige tap og utfordringer). Informantene beskrev avdøde som samvittighetsfulle, handlingsorienterte og dyktige i sitt arbeid (10). De ble også beskrevet som emosjonelt distanserte, gjenstridige og med behov for kontroll, noe som hadde bidratt til å skape konflikter i nære forhold. Det å motta hjelp hadde vært vanskelig for dem. Det ville innebære å gi slipp på kontrollen, noe som gikk på tvers av deres selvbilde/ identitet (10). Det kan dermed se ut som deres styrke og evne til å håndtere vanskeligheter gjennom livet nettopp var det som gjorde dem sårbare for selvmord $i$ alderdommen, fordi de ikke ville eller kunne tilpasse seg til aldersrelaterte tap ved å utvikle nye mestringsstrategier eller motta nødvendig hjelp $(9,10)$. Aldersrelaterte funk- sjonstap førte til en følelse av å ha mistet seg selv, siden de ikke lenger kunne gjøre det de ville. Livet ble dermed oppfattet som en byrde. De hadde et realistisk syn på fremtiden, en fremtid de ikke ønsket, og tok derfor et eksistensielt valg om å ta sitt liv. På den måten tok de tilbake kontrollen. Tittelen på Kjølseths doktoravhandling er da også «Control in life - and in death: an understanding of suicide among the elderly» (9).

I Rasmussens studie av selvmord blant unge menn (11) inngikk kun menn som ikke hadde vært i kontakt med psykisk helsevern, og som ikke tidligere hadde gjort selvmordsforsøk. Dybdeintervjuer med mor, far, søsken, kjærester og venner, samt avdødes avskjedsbrev, gjorde det mulig å analysere data i både utviklingsog relasjonsperspektiv. Som i Kjølseths studie, ble også de unge mennene beskrevet som flinke og prestasjonsorienterte $\mathrm{i}$ jobb og studier. Flere ble beskrevet som perfeksjonister. Til tross for at de fremsto som suksessfulle, viste imidlertid analysen at de tidlig i livet hadde utviklet en skjør prestasjonsbasert selvfølelse som gjorde dem sårbare, selv i møte med små nederlag. Studien avdekker en særlig sårbarhet for å oppleve seg som mislykket og avvist når de ikke lyktes i å leve opp til sitt idealbilde av hva de skulle prestere, og hvordan de hadde sett for seg at livet skulle være. Istedenfor å senke prestasjonskravene i slike situasjoner ble de overmannet av sterke følelser, spesielt skam og sinne, som de verken var i stand til å regulere eller håndtere. Den tidligere strategien som innebar kompensasjon ved stadig å øke prestasjonene, fungerte ikke lenger, og selvmordet ble veien ut av en tilstand av uutholdelig psykisk smerte (12).

Et interessant funn $\mathrm{i}$ begge disse studiene er at informantene la liten vekt på psykiske lidelser i sine fortellinger om hva som var sentralt for avdødes selvmord. Få informanter hadde sett tegn på alvorlig psykisk lidelse (11), og mange uttrykte eksplisitt at avdøde $i k k e$ hadde vært deprimert $(11,13)$. Dette står i sterk kontrast til det som er konklusjonen i de fleste kvantitative 
PA-studier, nemlig at nesten alle som har tatt sitt liv, ble funnet å ha én eller flere psykiske lidelser (3), med tilhørende kausale implikasjoner. Funnene utfordrer dermed den etablerte oppfatningen om at selvmord primært er et symptom på en psykisk lidelse.

\section{Er det så farlig da?}

Spørsmålet er så om det gjør noe at det stadig påstås at psykiske lidelser spiller en viktig rolle i ni av ti selvmord. Det er selvsagt viktig å behandle psykiske lidelser, også i selvmordsforebyggende hensikt, men et overdrevent fokus på «90\%-sannheten» kan ha flere uheldige konsekvenser.

Dyregrov (14) har tidligere beskrevet dette som en «farlig diskurs». Én uheldig konsekvens er at det kan bre seg en oppfatning om at så lenge det ikke er tegn til psykisk sykdom, er det ingen fare på ferde (14). Som det går frem av Rasmussen og kollegers studie (12), kan dette bli skjebnesvangert.

En annen konsekvens er at når det fokuseres på psykiske lidelser som «hovedårsaken» til selvmord, ligger det implisitt i dette at det viktigste man kan gjøre for å forebygge selvmord, er å diagnostisere og behandle psykiske lidelser. Dette sies da også ofte eksplisitt (3), og psykisk helsevern beskrives som «vårt viktigste redskap for å forebygge selvmord» (15). Søkelyset rettes dermed mot enkeltindividet, der suicidaliteten blir sett på som noe som ligger $i$ individet, samtidig som betydningen av kontekst og relasjoner får mindre oppmerksomhet (16). Dette kan igjen føre til en oppfatning om at man nærmest må være psykiater eller psykolog for å kunne bidra til å forebygge selvmord. Det er uheldig.

Hva da med alle dem som ikke er i kontakt med helsevesenet før et selvmord (11)? For å si det med den internasjonale selvmordsforebyggingsforeningen: «Prevention of suicide is everybody's business» (17). Alle kan bidra til å forebygge selvmord. Dette er et viktig budskap å få frem, og den stadige gjentakelsen av $« 90 \%$ sannheten» fra toneangivende fagfolk står $i$ veien for dette.

\section{Konklusjon}

Vi vil understreke at vi på ingen måte hevder å ha «motbevist» at det er en sammenheng mellom psykiske lidelser og selvmord. Mange som tar sitt eget liv, har antakelig en psykisk lidelse. Vårt poeng er at det ikke finnes valid forskningsevidens for å hevde at dette gjelder så godt som alle.

Det er også viktig å få frem at selv i noen av de tilfellene der det forelå en klar psykisk lidelse, er det slett ikke sikkert at denne i seg selv var avgjørende for selvmordet. Mange har vært psykisk syke i lang tid før et selvmord. Dette, sammen med det faktum at de aller fleste som har én eller flere psykiske lidelser, ikke tar sitt liv, gjør det åpenbart at selvmord handler om langt mer, og kanskje noe helt annet, enn psykiske lidelser (16). Da kan det være kontraproduktivt stadig å vise til « $190 \%$-sannheten», særlig i de sammenhenger der man forsøker å få frem et mer nyansert bilde, som i Aftenposten A-magasinet 4. april $(2,18)$.

I det selvmordsforebyggende arbeidet er det på høy tid å fokusere mer på kompleksiteten som alltid ligger bak et selvmord. Den biomedisinske sykdomsmodellen kommer til kort når det gjelder å forebygge selvmord. Vi blir nødt til å ta inn også det kontekstuelle og relasjonelle i et livsløpsperspektiv hvis vi ønsker å forstå hva selvmord handler om (16).

\section{Heidi Hjelmeland (f. 1960)}

er professor i helsevitenskap ved Institutt for sosialt arbeid og helsevitenskap, NTNU, og rådgiver ved Ressurssenter om vold, traumatisk stress og selvmordsforebygging, Region Midt.

Forfatter har fylt ut ICMJE-skjemaet og oppgir ingen interessekonflikter.

\section{Gudrun Dieserud (f. 1944)}

er seniorforsker ved Avdeling for helseovervåking og selvmordsforebygging, Divisjon for psykisk helse, Nasjonalt folkehelseinstitutt, og psykologspesialist ved Selvmordsforebyggende team, Bærum kommune.

Forfatter har fylt ut ICMJE-skjemaet og oppgir ingen interessekonflikter.

\section{Kari Dyregrov (f. 1951)}

er forskningsleder ved Senter for Krisepsykologi, og professor II ved Avdeling for helseog sosialfag, Høgskolen i Bergen.

Forfatter har fylt ut ICMJE-skjemaet og oppgir ingen interessekonflikter.

\section{Birthe Loa Knizek (f. 1957)}

er professor i psykisk helsearbeid ved Avdeling for sykepleierutdanning. Høgskolen i Sør-Trøndelag, og klinisk psykolog.

Forfatter har fylt ut ICMJE-skjemaet og oppgir ingen interessekonflikter.

\section{Mette Lyberg Rasmussen (f. 1966)}

er psykolog og postdoktor ved Avdeling for helseovervåking og selvmordsforebygging, Divisjon for psykisk helse, Nasjonalt folkehelseinstitutt.

Forfatter har fylt ut ICMJE-skjemaet og oppgir ingen interessekonflikter.
Litteratur

1. Gjelsvik B. Advarsel om selvmordsrisiko. Tidsskr Nor Psykol Foren 2014: 51: 243-5.

2. Halvorsen BE. Lars Mehlum: Bekymret for prestasjonsjaget. Aftenposten, A-magasinet 4.4.2014: 33

3. Cavanagh JTO, Carson AJ, Sharpe M et al. Psychological autopsy studies of suicide: a systematic review. Psychol Med 2003; 33: 395-405.

4. Pouliot L, De Leo D. Critical issues in psychological autopsy studies. Suicide Life Threat Behav 2006: 36: 491-510.

5. Hjelmeland H, Dieserud G, Dyregrov K et al. Psychological autopsy studies as diagnostic tools: are they methodologically flawed? Death Stud 2012 36: $605-26$

6. Conner KR, Beautrais AL, Brent DA et al. The next generation of psychological autopsy studies. Part I. Interview content. Suicide Life Threat Behav 2011 : 41: $594-613$

7. Owens C, Booth N, Briscoe M et al. Suicide outside the care of mental health services: a case-controlled psychological autopsy study. Crisis 2003; 24 : $113-21$

8. Owens C, Lambert H. Mad, bad or heroic? Gender identity and accountability in lay portrayals of suicide in late twentieth-century England. Cult Med Psychiatry 2012; 36: 348-71.

9. Kjølseth I. Control in life - and in death. An under standing of suicide among the elderly. Doktoravhandling. Oslo: Det medisinske fakultet, Universitetet i Oslo, 2010

10. Kjølseth I, Ekeberg O, Steihaug S. «Why do they become vulnerable when faced with the challenges of old age?» Elderly people who committed suicide, described by those who knew them. Int Psychogeriatr 2009; 21: 903-12.

11. Rasmussen ML. Suicide among young men: Selfesteem regulation in transition to adult life. Doktoravhandling. Oslo: Det samfunnsvitenskapelige fakultet, Universitetet i Oslo, 2013.

12. Rasmussen ML, Haavind H, Dieserud $G$ et al. Exploring vulnerability to suicide in the developmental history of young men: A psychological autopsy study. Death Stud 2013; doi 10.1080/ 07481187.2013.780113.

13. Kjølseth I, Ekeberg O, Steihaug S. Why suicide? Elderly people who committed suicide and their experience of life in the period before their death. Int Psychogeriatr 2010: 22: 209-18.

14. Dyregrov K. En farlig diskurs ved forståelse av selvmord. Tidsskr Nor Psykol foren 2008; 45: 2-3.

15. Mehlum L, Ness E, Walby FA. Re: Overdreven tro på selvmordsrisikovurderinger? Tidsskr Nor Legeforen 2014: 134: 593

16. Hjelmeland H, Knizek BL. Hva er meningen? Selv mordsatferd som kommunikasjon. Sosiologi i dag 2013; 43: 7-30.

17. International Association for Suicide Prevention. World Suicide Prevention Day Brochure, 2005. www.iasp.info/wspd/2005_wspd_activities.php (16.6.2014)

18. Halvorsen BE. Mette Lyberg Rasmussen: Utad er de vellykkede, unge menn. Så tar de livet sitt. Aftenposten, A-magasinet 18.4.2014: 24-33.

Mottatt 15.4. 2014, første revisjon innsendt 30.5. 2014, godkjent 16.6. 2014. Redaktør: Kari Tveito. 